Gelanggang Olahraga: Jurnal Pendidikan Jasmani dan Olahraga

Volume 2, Nomor 2, Januari-Juni 2019

e-ISSN : 2597-6567

p-ISSN : 2614-607X

DOI : https://doi.org/10.31539/jpjo.v2i2.697

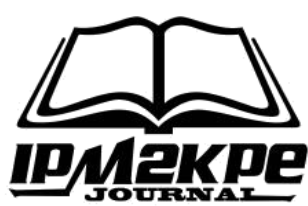

\title{
KONDISI FISIK PEMAIN BOLA VOLI KLUB DI KOTA LUBUKLINGGAU
}

\author{
Ever Sovensi $^{1}$, Muhammad Supriyadi ${ }^{2}$, Muhammad Suhdy ${ }^{3}$ \\ STKIP-PGRI Lubuklinggau ${ }^{1,2,3}$ \\ Ever_sovensi@yahoo.co.id ${ }^{1}$
}

\begin{abstract}
ABSTRAK
Tujuan penelitian untuk mengetahui kondisi fisik pemain bolavoli Club Caroline dan Club JVC kota Lubuklinggau tahun 2018. Jenis penelitian ini bersifat deskriptif kuantitatif. Populasi dari penelitian ini adalah pemain bolavoli putra Club Caroline dan Club JVC kota Lubuklinggau yang seluruh pemainnya 45 orang, yang terdiri dari 25 pemain Club Caroline dan 20 pemain Club JVC. Sampel pada penelitian ini berjumlah 45 pemain, yang diambil dengan menggunakan teknik total sampling. Hasil penelitian ini menjelaskan bahwa, daya ledak otot tungkai yang dimiliki pemain bolavoli klub Caroline rata-rata 108,23 dikategorikan Cukup, sedangkan rata-rata tingkat daya ledak otot tungkai yang dimiliki oleh pemain bolavoli klub JVC adalah 115,18 dikategorikan Baik. Selanjutnya, Hasil tes daya tahan yang dimiliki pemain bolavoli klub Carolin rata-rata 32,6 dikategorikan cukup, sedangkan rata-rata tingkat daya tahan yang dimiliki oleh pemain bolavoli Klub Caroline adalah 37,7 dikategorikan sedang. Simpulan, daya ledak otot tungkai pemain bolavoli klub Caroline dikategorikan cukup dan daya ledak otot tungkai pemain bolavoli klub JVC dikategorikan baik. Daya tahan pemain bolavoli klub Caroline dikategorikan cukup dan yang dimiliki pemain bolavoli Klub JVC dikategorikan sedang. Selanjutnya, Kecepatan pemain bolavoli klub Caroline dan JVC kategori baik. Sedangkan kelincahan pemain pembolavoli klub Caroline dikategorikan baik dan kelincahan pemain bolavoli klub JVC dikategorikan Sedang. Selanjutnya, kekuatan otot perut pemain bolavoli klub Caroline dan JVC masuki kategori Baik.
\end{abstract}

Kata Kunci: Kondisi Fisik, Bolavoli

\section{ABSTRACT}

The research objective was to determine the physical condition of Club Caroline volleyball players and Lubuklinggau City Club JVC in 2018. This type of research was descriptive quantitative. The population of this study were male volleyball players Club Caroline and Lubuklinggau City Club JVC with all 45 players, consisting of 25 Club Caroline players and 20 Club JVC players. The sample in this study amounted to 45 players, which were taken using total sampling technique. The results of this study explained that the explosive strength of leg muscles possessed by Caroline club volleyball players averaged 108.23 categorized as Enough, while the average explosive power level the limbs owned by JVC club volleyball players are 115.18 categorized Good. Furthermore, the endurance test results possessed by Carolin club volleyball players an average of 
32.6 are categorized sufficient, while the average endurance level possessed by Caroline Club volleyball players is 37.7 categorized as moderate. Conclusion, the explosive strength of limb muscles of the Caroline club volleyball player is categorized enough and the explosive strength of the leg muscles of the JVC club players is categorized as good. The durability of Caroline's club volleyball players is categorized enough and those possessed by JVC Club volleyball players are categorized as being moderate. Furthermore, the speed of Caroline club volleyball players and JVC is good. Whereas the agility of the Caroline club players is categorized as good and the agility of the JVC club volleyball players is categorized as Moderate. Furthermore, the abdominal muscle strength of club volleyball players Caroline and JVC entered the Good category.

\section{Keywords: Physical Condition, Bolavoli}

\section{PENDAHULUAN}

Olahraga memiliki banyak tujuan, diantaranya adalah prestasi. Olahraga prestasi di Indonesia mendapat perhatian lebih oleh pemerintah pusat dan daerah, sehingga nantinya diharapkan pengembangan dan pembinaan prestasi dapat dilakukan lebih serius sehingga melahirkan atlet yang berprestasi baik di tingkat daerah, nasional bahkan intenasional sekalipun. Sesuai dengan tujuan prestasi yang tercantum dalam UU RI No. 3 tahun 2005 Pasal 20 ayat 3 yang menyatakan : "Olahraga prestasi dilaksanakan melalui proses pembinaan dan pengembangan secara terencana, berjenjang, dan berkelanjutan dengan dukungan ilmu pengetahuan dan teknologi keolahragaan". Berdasarkan kutipan di atas, maka pembinaan dan pengembangan keolahragaan nasional yang dapat menjamin pemerataan akses terhadap cabang olahraga, peningkatan kualitas hidup manusia, baik secara jasmani maupun rohani. Di samping itu, melalui pembinaan olahraga dapat meningkatkan prestasi.

Salah satu cabang olahraga yang sangat berkembang di Indonesia adalah cabang olahraga bolavoli. Cabang voli juga diharapkan mampu mengharumkan nama bangsa dan negara di event internasional. Banyak elemen yang dapat mempengaruhi dalam prestasi olahraga bolavoli diantaranya kondisi fisik, teknik, strategi, taktik, dan mental. Hal ini sejalan dengan pendapat Syafruddin (2011) prestasi dipengaruhi dan ditentukan oleh kelompok atlet itu sendiri secara menyeluruh baik menyangkut kondisi fisik, keterampilan teknik, pengetahuan taktik, dan mental. Berdasarkan pendapat tersebut, kondisi fisik merupakan elemen yang sangat menunjang dalam pencapaian prestasi yang optimal.

Menurut (Syarifuddin 2011) kondisi fisik merupakan salah satu faktor penentu keberhasilan penerapan konsep-konsep taktik. Berdasarkan pendapat di atas maka tanpa kondisi fisik yang baik, maka sulit bagi setiap atlet untuk menguasai teknik dan tanpa menguasai teknik maka tidak akan bisa menerapkan rencana taktik yang baik dan hal ini akan berpengaruh terhadap mental atlet. Dengan kata lain, untuk menguasai teknik dan menerapkan taktik yang baik harus didukung $\mathrm{k}$ kondisi fisik yang baik terlebih dahulu. Faktor-faktor kondisi fisik yang mempengaruhi prestasi menurut Syafruddin (2011), antara lain: kekuatan (strength), daya tahan (endurance), daya ledak (eksplosif power), kecepatan (speed), kelentukan (flexibility), kelincahan (agility), reaksi (reaction). 
Dari uraian di atas dapat dikemukakan bahwa komponen-komponen kondisi fisik seperti kekuatan otot perut, daya tahan, daya ledak otot tungkai, kecepatan dan kelincahan merupakan elemen yang sangat menunjang prestasi dalam cabang olahraga bolavoli. Dengan demikian dapat dikatakan atau dapat diartikan kemampuan kondisi fisik sebagai fundamental dalam suatu cabang olahraga, khususnya cabang olahraga bolavoli. Sehingga jelas kondisi fisik yang baik merupakan syarat penting dalam mencapai prestasi puncak. Selain hal di atas banyak factor yang mempengaruhi prestasi diantaranya sumber dana, ketersediaan sarana dan prasarana, kualitas pelatih dan postur tubuh. Karena postur tubuh yang ideal untuk atlet bolavoli ditetapkan sebagai syarat minimal untuk putra $175 \mathrm{~cm}$ dan putri $165 \mathrm{~cm}$ PBVSI (1995).

Club Caroline dan Club JVC merupakan club bolavoli yang aktif di kota Lubuklinggau. Hal ini terlihat setelah penulis observasi awal kelapangan dan wawancara langsung pada pelatih. Club ini melaksanakan latihan rutin 3-4 kali dalam seminggu yang dibimbing oleh pelatih-pelatih professional. Selain itu, clubclub ini memiliki sarana dan prasarana yang sudah memadai, hal ini tergambar dengan jumlah bolavoli yang dimiliki sebanyak 15-20 buah. tersedianya lapangan yang layak yaitu 2 lapangan voli indoor. Selanjutnya masing-masing club ini juga sudah memiliki ruang fitness sebagai wadah pembentukan kondisi fisik untuk menunjang keberhasilan program latihan. Kelengkapan sarana dan prasarana ini tidak lepas dari manajemen dan dukungan pemilik club yaitu ibu $\mathrm{Hj}$. Caroline, $\mathrm{S} . \mathrm{H}$ sebagai pemilik club caroline dan ibu $\mathrm{Hj}$. Lely Yuniar pemilik club JVC.

Melihat gambaran di atas, dengan aktifnya melaksanakan latihan, ketersediaan sarana dan prasarana yang memadai, pelatih yang professional serta dukungan pemilik club yang baik seharusnya para pemain sudah memiliki kemampuan kondisi fisik yang baik, karena kondisi fisik merupakan elemen yang penting untuk menunjang baik buruknya kemampuan teknik seseorang. Hal ini sejalan dengan pendapat (Syarifuddin 2011) kondisi fisik merupakan salah satu faktor penentu keberhasilan penerapan konsep-konsep taktik.

Berdasarkan pendapat di atas, maka kondisi fisik yang baik wajib dimiliki setiap pemain untuk bisa mencapai prestasi yang optimal. Selain itu, data kemampuan kondisi fisik pemain merupakan acuan dasar seorang pelatih untuk menyusun program latihan peningkatan kondisi. Dengan demikian, data kondisi fisik pemain harus dimiliki seorang pelatih sebagai acuan menetukan materi dan metode yang akan diterapkan sesuai kebutuhan latihan. Akan tetapi, setelah peneliti wawancara dengan pelatih, masing-masing club ini belum memiliki dokumen tertulis data kondisi fisik pemain. Berdasarkan hal di atas maka penulis tertarik untuk melakukan penelitian tentang kondisi fisik pemain bolavoli Club di Kota Lubuklinggau tahun 2018.

\section{KAJIAN TEORI}

Jonath dan Krempel dalam (Syafruddin, 2011) mendefinisikan daya ledak sebagai kemampuan kombinasi kekuatan dan kecepatan yang terealisasi dalam bentuk kemampuan otot untuk mengatasi beban dengan kecepatan kontraksi yang tinggi. Dengan demikian, daya ledak otot tungkai merupakan salah satu komponen fisik yang harus dimiliki seorang atlet bolavoli,karena sangat menunjang dalam keberhasilan melakukan smash, block, receive maupun servis jump. 
Ketinggian lompatan vertikal yang optimal akan memudahkan seorang atlet melakukan smash, dan blocking secara benar, untuk itu setiap atlet bolavoli, dituntut memiliki kemampuan melompat vertikal secara sempurna. Kemampuan melompat harus dikembangkan pada setiap atlet bolavoli, meningkatkan kemampuan melompat vertikal salah satunya dengan melatih otot tungkai untuk menghasilkan daya ledak guna untuk menunjang smasher yang akan melakukan serangan ke daerah lawan dalam permainan bolavoli.

Menurut Syafrudddin (2011) daya tahan merupakan salah satu elemen kondisi fisik yang terpenting karena merupakan pondasi atau dasar untuk pengembangan elemen kondisi fisik yang lain. Menurut Bafirman dan Apri Agus (2008) daya tahan diartikan sebgai waktu bertahan yaitu lamanya seseorang dapat melakukan suatu intensitas kerja atau jauh dari keletihan. Dengan demikian kemampuan daya tahan yang baik sangat dibutuhkan dalam permainan bolavoli, karena menurunnya daya tahan akan mempengaruhi kualitas teknik seorang pemain.

Selanjutnya, Menurut Bompa dan Haff dalam Syafruddin (2011) kecepatan merupakan kemampuan untuk menyelesaikan suatu jarak tertentu dengan cepat. Sedangkan menurut Apri Agus (2012) kecepatan merupakan kemampuan seseorang untuk mengerjakan gerakan berkesinambungan dalam bentuk yang sama dengan waktu sesingkat-singkatnya. Dari pendapat diatas dapat disimpulkan bahwa kecepatan merupakan kemampuan tubuh untuk bergerak dengan cepat untuk melawan beban, jarak dan waktu. Pada cabang olahraga bolavoli kecepatan yang baik dapat mempermudah penguasaan teknik bermain, efektif dan efesien.

Soejono dalam Harsono (2001) berpendapat bahwa kelincahan adalah kemampuan mengubah arah secara cepat arah tubuh atau bagian tubuh tanpa gangguan pada keseimbangan. Ini berarti bahwa kelincahan adalah kemampuan seseorang untuk merubah arah dan posisinya yang dikehendaki dengan cepat dan tepat sesaat sedang bergerak tanpa kehilangan kesadaran dan keseimbangan sesuai dengan situasi dan kondisi yang dihadapi.

Pada cabang olahraga bolavoli kelincahan yang baik dapat mempermudah penguasaan teknik bermain, efektif dan efesien dalam pengguna tenaga. Selain itu kelincahan mempermudah orentasi lingkungan dan gerakan teman seregu serta gerakan bermain, melakukan gerak tipu dengan bola atau melakukan smash dan mematikan serangan lawan dengan gerakan tiba-tiba dan cepat dalam merubah arah. Kelincahan dalam memainkan bola sering membantu pemain dalam mengatasi situasai yang sulit seperti saat di serang oleh pemain lawan. Sedikit saja bola jatuh dari jangauan maka bola akan jatuh di daerah sendiri dan tentu saja lawan mendapatkan penambahan angka (poin). Mengingat banyaknya komponenkomponen yang ikut mempengaruhi kelincahan maka dapat dikatakan bahwa kelincahan merupakan suatu komponen yang sangat penting dalam permainan bolavoli.

Fox Dalam Arsil (2000) mengatakan kekuatan otot adalah daya atau tekanan sebuah otot, atau lebih tepatnya adalah suatu kelompok otot yang dapat digunakan melawan suatu perlawanan di dalam suatu usaha/upaya maksimal. Dari pendapat tersebut dapat disimpulkan bahwa kekuatan adalah kemampuan otot atau sekelompoknya dalam usahanya menahan beban atau pekerjaan dalam waktu yang relatif pendek. Kekuatan yang dimaksudkan di sini adalah kekuatan khusus. Bompa dalam Arsil (2000) mengemukakan bahwa kekuatan khusus ini berkenaan 
dengan otot yang dipergunakan dalam penampilan gerak sesuai cabang olahraganya khususnya cabang olahraga bolavoli.

Kekuatan otot perut dapat meningkatkan unjuk kerja keterampilan motorik mempunyai peranan yang sangat menentukan untuk kemampuan smash bolavoli. Atlet yang memiliki kekuatan otot perut yang baik dapat melakukan ayunan tubuh dengan kuat dan akan lebih mudah membantu pergerakan dalam smash. Sebaliknya atlet yang kurang memiliki kekuatan otot perut kesulitan melakukan pergerakan tubuh sehingga smash yang dihasilkan lemah dan tidak terarah. Keberhasilan unjuk kerja keterampilan motorik sangat tergantung dari sifat bangun individu yaitu kemampuan atlet dalam menggerakkan kekuatan otot perut yang menjadi komponen utama keterampilan motorik.

\section{METODE PENELITIAN}

Penelitian ini bersifat deskriptif kuantitatif, yang bertujuan untuk mengungkapkan Bagaimana Kondisi Fisik Pemain Bolavoli Club Caroline dan Club JVC Kota Lubuklinggau Tahun 2018. Penelitian ini dilaksanakan di lapangan bolavoli Club Caroline dan Club JVC Kota Lubuklinggau pada bulan Oktober 2018.Populasi pada penelitian ini adalah seluruh pemain bolavoli putra Club Caroline dan Club JVC kota Lubuklinggau tahun 2018 yang terdaftar mengikuti latihan. Seluruh pemainnya 45 orang, yang terdiri dari 25 pemain Club Caroline dan 20 pemain Club JVC. Karakteristik sampel ditetapkan secara total sampling,. Berpedoman pada tabel populasi di atas, maka sampel pada penelitian ini yaitu seluruh pemain putra Club Caroline dan Club JVC kota Lubuklinggau tahun 2018 yang berjumlah 45 orang. Jenis data yang digunakan dalam penelitian ini adalah data primer, yang diambil langsung dari hasil tes kondisi fisik terhadap pemain bolavoli putra Club Caroline dan Club JVC Kota Lubuklinggau tahun 2018 yang meliputi daya ledak otot tungkai, daya tahan, kecepatan dan kelincahan serta kekuatan otot perut yang didapat dari tes secara langsung terhadap semua sampel yang ditetapkan.

\section{Instrument Penelitian}

Instrumentasi penelitian menggunakan Vertical Jump Test untuk mengukur kemampuan daya ledak otot tungkai, metode bleep test untuk mengukur daya tahan, Tes Lari 30 m untuk mengukur kemampuan kecepatan, Shuttle Run Test untuk mengukur kelincahan dan Sit-up Test untuk mengukur kekuatan otot perut.

\section{Vertical Jump Tes}

\begin{tabular}{ll}
\hline Tujuan & Untuk mengukur daya ledak otot tungkai \\
\hline Alat & Papan skala, penghapus papan skala, serbuk kapur \\
\hline
\end{tabular}

Cara pelaksanaan. Papan digantungkan pada dinding setinggi raihan testee, sebelumnya tangan testee ditaburi serbuk kapur, testee siap berdiri di bawah papan skala dan tangan meraih setinggi-tingginya ke atas dan ditempelkan pada papan skala, sehingga bekas tangan yang diberi serbuk kapur dibaca pada skala yang ada pada papan berskala tersebut (titik A), setelah itu testee mengambil 
sikab melompat tinggi ke atas sambil menepuk papan skala pada saat berada di puncak lompatan (titik B), selisih antara B-A dijadikan inci,setelah itu di bandingkan dengan berat badan atau dengan rumus nomogramlewis: $(\sqrt{ } 4,9$ (berat badan) $\mathrm{x} \sqrt{ }$ selisih $)$. Hasil tersebut adalah prestasi testee (daya ledak otot tungkai).

\section{Daya Tahan (metode Bleep/Multi Tahap)}

Fasilitas dan alat : Lintasan yang datar, Meteran, Kaset dan tape recorder, Kerucut, Stopwat; Petugas : Pengukur jarak, Petugas start, Pengawas lintasan, Pencatat skor; Pelaksanaan : tes bleep dilakukan dengan lari menempuh jarak 20 $\mathrm{m}$ bolak-balik, yang didimulai dengan lari pelan-pelan secara bertahap yang semakin lama semakin cepat hingga atlet tidak mampu mengikuti irama waktu lari, berarti kemampuan maksimalnya pada level bolak-balik tersebut.

\section{Kecepatan}

Tes lari 30 meter. Prosedur pelaksanaan test kecepatan lari 30 meter 1) testee siap berdiri di belakang garis start; 2) dengan aba-aba "siap" testee siap berlari dengan start berdiri; 3 ) dengan aba-aba "ya" testee berlari secepat-cepatnya dengan menempuh jarak 30 meter sampai melewati garis akhir; 4) kecepatan lari dihitung dari aba-aba "ya"; 5) pencatatan waktu dilakukan sampai dengan persepuluh detik $(0,1$ detik), bila memungkinkan dicatat, sampai dengan peseratus detik $(0,01$ detik); 6) testee dilakukan dua kali, pelari melakukan test berikutnya setelah berselang minimal satu pelari. Kecepatan lari yang terbaik yang di hitung; 7) testee dinyatakan gagal apabila melewati atau menyeberangi lintasan lainnya

\section{Kelincahan diukur dengan Shuttle Run Test (6x10 meter)}

Kelincahan diukur dengan alat meliputi; 1) alat : Stopwatch, alat ukur panjang (rol), cones (patok), pluit dan alat-alat tulis; 2) cara pelaksanaan; testee berdiri di belakang garis start (patok A), dengan salah satu kaki diletakkan di depan. Setelah pluid dibunyikan, testee dengan segerah dan secepat mungkin lari menuju garis finish akhir (patok B) dan menyentuh patok tersebut. Kemudian membalik dan segerah lari ke tempat semula. Demikian seterusnya dilakukan bolak-balik sehingga mencapai sebanyak 6 x 10 meter. Penilaian hasil dari testee berlari bolak-balik secepat mungkin diukur dengan alat ukur waktu (stopwatch) dan waktu inilah yang diambil sebagai data penilaian terhadap kelincahan.

\section{Tes Kekuatan Otot Perut}

Kekuatan otot perut dapat diukur dengan sit-up test selama 30 detik. (Mulyono, 2007: 62-63) meliputi; 1) perlengkapan :ILantai yang datar sebaiknya indoor dapat menggunakan matras atau karpet dan dua buah stopwatch; 2) pelaksanaan : testee tidur terlentang dengan lutut ditekuk dan kedua kaki selebar kurang lebih $25 \mathrm{~cm}$. Kedua jari-jari tangan dihubungkan dan diletakkan di belakang kepala. Seorang teman memegang kedua pergelangan kakinya dan menekan agar telapak kaki tetap melekat di lantai selama melakukan sit-up (30 detik). Dari sikap awal ini dimulai gerakan sit-up dengan posisi punggung menyentuh lantai dan kembali ditarik ke sikap semula. Ketika aba-aba "ya" testee melakukan sit-up bertepatan dengan dihidupkannya stopwatch hingga 30 detik; 3) penilaian : Jumlah sit-up yang benar adalah skor pengulangan terhadap tiap pelaksanaan sit-up yang benar selama 30 detik dan diambil sebagai data 
penelitian; 4) catatan, apabila kedua tangan terlepas atau tidak memegang kepala dan punggung tidak menyentuh lantai maka tidak dihitung sebagai skor.

\section{HASIL PENELITIAN}

\section{Daya Ledak Otot Tungkai}

\section{Daya Ledak Otot Tungkai Pemain Bolavoli Klub Caroline}

Berdasarkan hasil tes Vertical Jump untuk 25 pemain, diperoleh nilai maksimum 119,57 tergolong kategori Baik dan sekor minimum 96,43 tergolong kategori Cukup serta rata-rata 108,23 kg m/ceken tergolong kategori Cukup. Berdasarkan hasil analisis data daya ledak otot tungkai pemain bolavoli klub Caroline kota Lubuklinggau tahun 2018 diperoleh data distribusi frekuensi sebagai berikut:

Tabel 1

Distribusi Frekuensi Daya Ledak Otot Tungkai

\begin{tabular}{cccl}
\hline Norma penilaian & \multicolumn{2}{c}{ Frekuensi Absolut } & Kategori \\
\cline { 2 - 4 } & $\begin{array}{c}\text { Absolute } \\
(\text { Fa) }\end{array}$ & $\begin{array}{c}\text { Relatif } \\
(\boldsymbol{\%})\end{array}$ & \\
\hline$>301 \mathrm{~kg} \mathrm{~m} /$ ceken & 0 & 0,00 & Sempurna \\
\hline $240-300 \mathrm{~kg} \mathrm{~m} /$ ceken & 0 & 0,00 & Baik Sekali \\
\hline $115-239 \mathrm{~kg} \mathrm{~m} /$ ceken & 7 & 28,00 & Baik \\
\hline $54-114 \mathrm{~kg} \mathrm{~m} /$ ceken & 18 & 72,00 & Cukup \\
\hline $0-53 \mathrm{~kg} \mathrm{~m} /$ ceken & 0 & 00,00 & Kurang \\
\hline Jumlah & 25 & 100,00 & \\
\hline Rata-rata & $\begin{array}{c}\mathbf{1 0 8 , 2 3 ~ k g} \\
\text { m/ceken }\end{array}$ & \multicolumn{2}{c}{ Cukup } \\
\hline
\end{tabular}

\section{Daya Ledak Otot Tungkai Pemain Bolavoli Klub JVC}

Berdasarkan hasil tes Vertical Jump untuk 20 pemain, diperoleh nilai maksimum 134,08 tergolong kategori Baik dan sekor minimum 100,27 tergolong kategori Cukup serta rata-rata $115,18 \mathrm{~kg} \mathrm{~m} /$ ceken kategori Baik. Berdasarkan hasil analisis data daya ledak otot tungkai pemain bolavoli klub JVC kota Lubuklinggau tahun 2018 diperoleh data distribusi frekuensi sebagai berikut:

Tabel 2.

Distribusi Frekuensi Daya Ledak Otot Tungkai

\begin{tabular}{|c|c|c|c|}
\hline \multirow[t]{2}{*}{ Norma penilaian } & \multicolumn{2}{|c|}{ Frekuensi Absolut } & \multirow[t]{2}{*}{ Kategori } \\
\hline & $\begin{array}{c}\text { Absolute } \\
\text { (Fa) }\end{array}$ & $\begin{array}{c}\text { Relatif } \\
(\%)\end{array}$ & \\
\hline$>301 \mathrm{~kg} \mathrm{~m} /$ ceken & 0 & 0.00 & Sempurna \\
\hline $240-300 \mathrm{~kg} \mathrm{~m} /$ ceken & 0 & 0.00 & Baik Sekali \\
\hline $115-239 \mathrm{~kg} \mathrm{~m} /$ ceken & 10 & 50.00 & Baik \\
\hline $54-114$ kg m/ceken & 10 & 50.00 & Cukup \\
\hline $0-53 \mathrm{~kg} \mathrm{~m} /$ ceken & 0 & 00.00 & Kurang \\
\hline Jumlah & 20 & 100.00 & \\
\hline Rata-rata & $\begin{array}{c}115,18 \mathrm{~kg} \\
\text { m/ceken }\end{array}$ & & Baik \\
\hline
\end{tabular}




\section{Daya Tahan}

Daya Tahan Pemain Bolavoli Klub Caroline

Berdasarkan hasil tes Fungsi Kardiorespiratori VO2 Maks untuk 25 pemain, di peroleh skor maksimum 40,2 tergolong kategori sedang dan sekor minimum 29,5 tergolong kategori cukup. Dan rata-rata 31,08 tergolong kategori Sedang. Berdasarkan hasil analisis data daya tahan pemain bolavoli klub Caroline kota Lubuklinggau tahun 2018:

Tabel 3.

Distribusi Frekuensi Daya Tahan Pemain Bolavoli

\begin{tabular}{cccc}
\hline Norma penilaian & \multicolumn{2}{c}{ Frekuensi Absolut } & Kategori \\
\cline { 2 - 3 } & $\begin{array}{c}\text { Absolute } \\
(\text { Fa) }\end{array}$ & $\begin{array}{c}\text { Relatif } \\
(\boldsymbol{\%})\end{array}$ & \\
\hline 53 ke atas & 0 & 0,00 & Tinggi \\
\hline $43-52$ & 0 & 0,00 & Bagus \\
\hline $34-42$ & 5 & 20,00 & Cukup \\
\hline $25-33$ & 20 & 80,00 & Sedang \\
\hline 24 kebawah & 0 & 0,00 & Rendah \\
\hline Jumlah & 25 & 100,00 & Sedang \\
\hline Rata-rata & $\mathbf{3 1 , 0 8}$ & & \\
\hline
\end{tabular}

\section{Daya Tahan Pemain Bolavoli Klub JVC}

Berdasarkan hasil tes Fungsi Kardiorespiratori VO2 Maks untuk 20 pemain, di peroleh skor maksimum 45,2 tergolong kategori Bagus dan sekor minimum 31,8 tergolong kategori Sedang. Dan rata-rata 37,72 tergolong kategori Cukup. Berdasarkan hasil analisis data daya tahan pemain bolavoli klub JVC kota Lubuklinggau tahun 2018:

Tabel 4.

Distribusi Frekuensi Daya Tahan Pemain Bolavoli

\begin{tabular}{cccc}
\hline Norma penilaian & \multicolumn{2}{c}{ Frekuensi Absolut } & Kategori \\
\cline { 2 - 3 } & $\begin{array}{c}\text { Absolute } \\
(\mathbf{F a})\end{array}$ & $\begin{array}{c}\text { Relatif } \\
(\mathbf{\%})\end{array}$ & \\
\hline 53 ke atas & 0 & 00.00 & Tinggi \\
\hline $43-52$ & 4 & 20.00 & Bagus \\
\hline $34-42$ & 12 & 60.00 & Cukup \\
\hline $25-33$ & 4 & 20.00 & Sedang \\
\hline 24 kebawah & 0 & 0.00 & Rendah \\
\hline Jumlah & 20 & 100.00 & \\
\hline Rata-rata & $\mathbf{3 7 . 7 2}$ & & Cukup \\
\hline
\end{tabular}

\section{Kecepatan}

\section{Kecepatan Pemain Bolavoli Klub Caroline}

Berdasarkan hasil tes lari 30 meter untuk pemain, diperoleh nilai maksimum 5,05 tergolong kategori Kurang dan sekor minimum 3,68 tergolong kategori Baik Sekali. Berdasarkan hasil analisis data kecepatan pemain bolavoli klub Caroline kota Lubuklinggau tahun 2018 diperoleh data distribusi frekuensi sebagai berikut: 
Tabel 5.

Distribusi Frekuensi Kecepatan Pemain Bolavoli

\begin{tabular}{cccc}
\hline Norma penilaian & \multicolumn{2}{c}{ Frekuensi Absolut } & Kategori \\
\cline { 2 - 3 } & $\begin{array}{c}\text { Absolute } \\
(\mathbf{F a})\end{array}$ & $\begin{array}{c}\text { Relatif } \\
(\mathbf{\%})\end{array}$ & \\
\hline $3.58-3.91$ & 6 & 24,00 & Baik Sekali \\
\hline $3.92-4.34$ & 8 & 32,00 & Baik \\
\hline $4.35-4.72$ & 6 & 24,00 & Sedang \\
\hline $4.73-5.11$ & 5 & 20,00 & Kurang \\
\hline $5.12-5.50$ & 0 & 0,00 & Kurang Sekali \\
\hline Jumlah & 25 & 100,00 & Baik \\
\hline Rata-rata & $\mathbf{4 , 3 3}$ & & \\
\hline
\end{tabular}

\section{Kecepatan Pemain Bolavoli Klub JVC}

Berdasarkan hasil tes lari 30 meter untuk pemain, diperoleh nilai maksimum 4,85 tergolong kategori Kurang dan sekor minimum 3,64 tergolong kategori Baik Sekali. Berdasarkan hasil analisis data kecepatan pemain bolavoli klub JVC kota Lubuklinggau tahun 2018 diperoleh data distribusi frekuensi sebagai berikut:

Tabel 6.

Distribusi Frekuensi Kecepatan Pemain Bolavoli

\begin{tabular}{cccc}
\hline Norma penilaian & \multicolumn{2}{c}{ Frekuensi Absolut } & Kategori \\
\cline { 2 - 4 } & $\begin{array}{c}\text { Absolute } \\
(\text { Fa) }\end{array}$ & $\begin{array}{c}\text { Relatif } \\
(\boldsymbol{\%})\end{array}$ & \\
\hline $3.58-3.91$ & 5 & 25,00 & Baik Sekali \\
\hline $3.92-4.34$ & 7 & 35,00 & Baik \\
\hline $4.35-4.72$ & 4 & 20,00 & Sedang \\
\hline $4.73-5.11$ & 4 & 20,00 & Kurang \\
\hline $5.12-5.50$ & 0 & 0,00 & Kurang Sekali \\
\hline Jumlah & 20 & 100,00 & Baik \\
\hline Rata-rata & $\mathbf{4 , 2 8}$ & & \\
\hline
\end{tabular}

\section{Kelincahan}

\section{Kelincahan Pemain Bolavoli Klub Caroline}

Berdasarkan hasil tes lari bolak balik untuk pemain, diperoleh nilai maksimum 15,71 tergolong kategori Kurang dan sekor minimum 12,08 tergolong kategori Baik Sekali. Berdasarkan hasil analisis data kelincahan pemain bolavoli klub Caroline kota Lubuklinggau tahun 2018 diperoleh data distribusi frekuensi sebagai berikut:

Tabel 7.

Distribusi Frekuensi Kelincahan bolavoli

\begin{tabular}{cccc}
\hline $\begin{array}{c}\text { Norma penilaian } \\
\text { (detik) }\end{array}$ & \multicolumn{2}{c}{ Frekuensi Absolut } & Kategori \\
\cline { 2 - 4 } & $\begin{array}{c}\text { Absolute } \\
(\text { Fa) }\end{array}$ & $\begin{array}{c}\text { Relatif } \\
(\mathbf{\%})\end{array}$ & \\
\hline Ke atas 12.10 & 2 & 08,00 & Baik Sekali \\
\hline $12.11-13.53$ & 13 & 52,00 & Baik \\
\hline $13.54-14.96$ & 8 & 32,00 & Sedang \\
\hline $14.97-16.39$ & 2 & 08,00 & Kurang \\
\hline $16.40-$ ke bawah & 0 & 0,00 & Kurang Sekali \\
\hline Jumlah & 25 & 100,00 & Baik \\
\hline Rata-rata & $\mathbf{1 3 , 5 2}$ & & \\
\hline
\end{tabular}




\section{Kelincahan Pemain Bolavoli Klub JVC}

Berdasarkan hasil tes lari bolak balik untuk pemain, diperoleh nilai maksimum 15,71 tergolong kategori Kurang dan sekor minimum 12,08 tergolong kategori Baik Sekali. Berdasarkan hasil analisis data kelincahan pemain bolavoli klub JVC kota Lubuklinggau tahun 2018 diperoleh data distribusi frekuensi sebagai berikut:

Tabel 8.

Distribusi Frekuensi Kelincahan bolavoli

\begin{tabular}{cccc}
\hline $\begin{array}{c}\text { Norma penilaian } \\
\text { (detik) }\end{array}$ & \multicolumn{2}{c}{ Frekuensi Absolut } & Kategori \\
\cline { 2 - 3 } & $\begin{array}{c}\text { Absolute } \\
(\text { Fa) }\end{array}$ & $\begin{array}{c}\text { Relatif } \\
(\boldsymbol{\%})\end{array}$ & \\
\hline Ke atas 12.10 & 1 & 5.00 & Baik Sekali \\
\hline $12.11-13.53$ & 10 & 50.00 & Baik \\
\hline $13.54-14.96$ & 8 & 40.00 & Sedang \\
\hline $14.97-16.39$ & 1 & 5.00 & Kurang \\
\hline $16.40-$ ke bawah & 0 & 0.00 & Kurang Sekali \\
\hline Jumlah & 20 & 100.00 & Sedang \\
\hline Rata-rata & $\mathbf{1 3 , 5 5}$ & &
\end{tabular}

\section{Kekuatan Otot Perut}

\section{Kekuatan Otot Perut Pemain Bolavoli Klub Caroline}

Berdasarkan hasil tes Sit-Up untuk pemain, diperoleh nilai maksimum 30 tergolong kategori Baik Sekali dan sekor minimum 13 tergolong kategori Cukup sedangkan nilai rata-rata 21,72 tergolong kategori Baik. Berdasarkan hasil analisis data Kekuatan otot perut pemain bolavoli klub Caroline kota Lubuklinggau tahun 2018 diperoleh data distribusi frekuensi sebagai berikut:

Tabel 9.

Distribusi Frekuensi Kekuatan Otot Perut Pemain bolavoli

\begin{tabular}{|c|c|c|c|}
\hline \multirow[t]{2}{*}{ Norma penilaian } & \multicolumn{2}{|c|}{ Frekuensi Absolut } & \multirow{2}{*}{$\begin{array}{l}\text { Kategori } \\
\text { Skala 5A }\end{array}$} \\
\hline & $\begin{array}{c}\text { Absolute } \\
\text { (Fa) }\end{array}$ & $\begin{array}{c}\text { Relatif } \\
(\%)\end{array}$ & \\
\hline$>31$ & 0 & 0.00 & Sempurna \\
\hline $26-30$ & 5 & 20.00 & Baik sekali \\
\hline $18-25$ & 14 & 56.00 & Baik \\
\hline $11-17$ & 6 & 24.00 & Cukup \\
\hline $00-10$ & 0 & 0.00 & Kurang \\
\hline Jumlah & 25 & 100.00 & \\
\hline Rata-rata & \multicolumn{2}{|c|}{21.72} & Baik \\
\hline
\end{tabular}

\section{Kekuatan Otot Perut Pemain Bolavoli Klub JVC}

Berdasarkan hasil tes Sit-Up untuk pemain, diperoleh nilai maksimum 32 tergolong kategori Sempurna dan sekor minimum 19 tergolong kategori Baik sedangkan nilai rata-rata 24,40 tergolong kategori Baik. Berdasarkan hasil analisis data Kekuatan otot perut pemain bolavoli klub JVC kota Lubuklinggau tahun 2018 diperoleh data distribusi frekuensi sebagai berikut: 
Tabel 10.

Distribusi Frekuensi Kekuatan Otot Perut Pemain bolavoli

\begin{tabular}{|c|c|c|c|}
\hline \multirow[t]{2}{*}{ Norma penilaian } & \multicolumn{2}{|c|}{ Frekuensi Absolut } & \multirow{2}{*}{$\begin{array}{c}\text { Kategori } \\
\text { Skala 5A }\end{array}$} \\
\hline & $\begin{array}{c}\text { Absolute } \\
\text { (Fa) }\end{array}$ & $\begin{array}{c}\text { Relatif } \\
(\%)\end{array}$ & \\
\hline$>31$ & 1 & 5.00 & Sempurna \\
\hline $26-30$ & 6 & 30.00 & Baik sekali \\
\hline $18-25$ & 13 & 65.00 & Baik \\
\hline $11-17$ & 0 & 0.00 & Cukup \\
\hline $00-10$ & 0 & 0.00 & Kurang \\
\hline Jumlah & 20 & 100.00 & \\
\hline Rata-rata & \multicolumn{2}{|c|}{24.40} & Baik \\
\hline
\end{tabular}

\section{PEMBAHASAN}

Rata-rata tingkat daya ledak otot tungkai yang dimiliki oleh pemain bolavoli klub Caroline 108,23 dikategorikan Cukup, sedangkan rata-rata tingkat daya ledak otot tungkai yang dimiliki oleh pemain bolavoli klub JVC adalah 115,18 dikategorikan Baik. Kategori tersebut belum maksimal karena untuk masuk kategori sempurna harus berada pada skor $>31$. Dalam permainan bolavoli diperlukan daya ledak otot tungkai ketika sedanga bermain terutama saat melakukan smash dan blok.

Rata-rata tingkat daya tahan yang dimiliki oleh pemain bolavoli Klub Caroline adalah 32,6 dikategorikan Cukup, sedangkan rata-rata tingkat daya tahan yang dimiliki oleh pemain bolavoli Klub Caroline adalah 37,7 dikategorikan Sedang. kategori tersebut belum maksimal karena untuk masuk kategori Tinggi harus berada pada skor 53 ke atas. Sedangkan Rata-rata tingkat kecepatan yang dimiliki oleh pemain bolavoli klub Caroline adalah 4,33 dikategorikan Baik, sedangkan rata-rata tingkat kecepatan yang dimiliki oleh pemain bolavoli klub JVC adalah 4,28 dikategorikan Baik. Kategori tersebut belum maksimal karena untuk masuk kategori Baik Sekali harus berada pada skor 3.58-3.91.

Selanjutnya, Rata-rata tingkat kelincahan yang dimiliki oleh pemain bolavoli klub Caroline adalah 13,52 dikategorikan Baik, sedangkan rata-rata tingkat kelincahan yang dimiliki oleh pemain bolavoli klub JVC adalah 13,55 dikategorikan Sedang. Sedeangkan Rata-rata tingkat kekuatan otot perut yang dimiliki oleh pemain bolavoli klub Caroline pada skor 21,7 dikategorikan Baik, sedangkan rata-rata tingkat kekuatan otot perut yang dimiliki oleh pemain bolavoli klub JVC pada skor 24,40 dikategorikan Baik. Kategori tersebut belum maksimal karena untuk masuk kategori Baik harus berada pada skor 9-10. Berdasarkan data yang diperoleh tersebut, secara umum tingkat kondisi pemain bolavoli klub Caroline dan klub JVC kota Lubuklinggau 2018 tergolong belum maksimal.

Berdasarkan uraian di atas, untuk menjamin kesiapan seorang pemain bolavoli, kesiapan kondisi fisik sangatlah penting bagi olahraga bolavoli, cabang olahraga bolavoli yang membutuhkan banyak gerakan dan beraktivitas tinggi. Oleh sebab itu kondisi fisik sangat berperan sekali dalam membantu perkembangan keterampilan pemain bolavoli klub Caroline dan klub JVC kota Lubuklinggau diamana kondisi fisik merupakan unsur utama dalam pencapaian prestasi. 
Hal ini sejalan dengan pendapat (Syarifuddin 2011) kondisi fisik merupakan salah satu faktor penentu keberhasilan penerapan konsep-konsep taktik. Berdasarkan pendapat di atas, maka tanpa kondisi fisik yang baik, maka sulit bagi setiap atlet untuk menguasai teknik dan tanpa menguasai teknik maka tidak akan bisa menerapkan rencana taktik yang baik dan hal ini akan berpengaruh terhadap mental atlet. Dengan kata lain, untuk menguasai teknik dan menerapkan taktik yang baik harus didukung kondisi fisik yang baik terlebih dahulu. Berdasarkan pendapat di atas, maka kondisi fisik yang baik wajib dimiliki setiap pemain untuk bisa mencapai prestasi yang optimal. Selain itu, data kemampuan kondisi fisik pemain merupakan acuan dasar seorang pelatih untuk menyusun program latihan peningkatan kondisi.

Dari pendapat di atas dapat disimpulkan bahwa kondisi fisik merupakan unsur yang sangat penting dalam setiap cabang olahraga, kondisi fisik memegang peranan yang sangat penting untuk menentukan prestasi dalam berolahraga. Oleh karena itu, kesiapan kondisi fisik sangatlah penting untuk bisa menunjang kemampuan teknik pemain bolavoli klub di kota Lubuklinggau yang lebih baik. Dengan demikian, tingkat kondisi fisik pemain bolavoli klub Caroline dan klub JVC kota Lubuklinggau yang dimiliki sekarang perlu ditingkatkan lagi dengan cara melakukan proses latihan yang terencana dan sistematis serta dilaksanakan secara kontinyu dan berkesinambungan untuk menghasilkan kondisi fisik yang lebih baik lagi

\section{SIMPULAN}

Berdasarkan hasil penelitian yang telah diuraikan pada BAB terdahulu dapat dikemukakan kesimpulan bahwa, hasil tes daya ledak otot tungkai yang dimiliki pemain bolavoli klub Caroline rata-rata 108,23 dikategorikan Cukup, sedangkan rata-rata tingkat daya ledak otot tungkai yang dimiliki oleh pemain bolavoli klub JVC adalah 115,18 dikategorikan Baik. Selanjutnya, Hasil tes daya tahan yang dimiliki pemain bolavoli klub Carolinde rata-rata 32,6 dikategorikan Cukup, sedangkan rata-rata tingkat daya tahan yang dimiliki oleh pemain bolavoli Klub Caroline adalah 37,7 dikategorikan Sedang. Hasil tes kecepatan yang dimiliki pemain Bolavoli klub Caroline rata-rata 4,33 dikategorikan Baik, dan rata-rata tingkat kecepatan yang dimiliki oleh pemain bolavoli klub JVC adalah 4,28 dikategorikan Baik. Selanjutnya, untuk hasil tes kelincahan yang dimiliki pemain pembolavoli klub Caroline rata-rata 13,52 dikategorikan Baik, sedangkan rata-rata tingkat kelincahan yang dimiliki oleh pemain bolavoli klub JVC adalah 13,55 dikategorikan Sedang. Sedangkan hasil tes kekuatan otot perut yang dimiliki pemain bolavoli klub Caroline rata-rata 21,7 dikategorikan Baik, sedangkan rata-rata tingkat kekuatan otot perut yang dimiliki oleh pemain bolavoli klub JVC pada skor 24,40 dikategorikan Baik 


\section{DAFTAR PUSTAKA}

Agus, A \& Bafirman. (2008). Pembentukan Kondisi Fisik. Padang: FIK UNP.

Arsil. (2000). Pembinaan Kondisi Fisik. Padang: Fakultas Ilmu Keolahragaan Universitas Negeri Padang

Harsono. (2001). Latihan Kondisi Fisik. Makalah disajikan dalam Penyegaran atau Penataran Para Pelatih Olahraga. Bandung

PBVSI. (1995_. Metodologi Pelatihan. Jakarta: Sekretariat Umum PP. PBVSI.

Syafruddin. (2011). Ilmu Kepelatihan Olahraga. Padang: UNP Press.

Undang-Undang Negara Ripublik Indonesia No. 3. 2005. Sistem Keolahragaan Nasional. Jakarta: Menpora. 